\title{
15. OXYGEN AND CARBON ISOTOPE STUDIES OF CARBONATE SEDIMENTS FROM SITE 167, MAGELLAN RISE, LEG $17^{1}$
}

\author{
Tyler B. Coplen and Seymour O. Schlanger, Department of Geological Science and Institute of Geophysics and \\ Planetary Physics, University of California, Riverside, California
}

\section{INTRODUCTION}

At Site 167 a nearly complete sedimentary section ranging in age from Pleistocene to Tithonian and composed almost entirely of calcareous ooze, chalk, cherty chalk, cherty limestone, and argillaceous limestone was drilled to a depth of approximately 1170 meters where the basaltic basement was reached. The relative continuity and age of the section makes it useful for studies of deep-sea diagenesis and paleotemperatures. This chapter presents the stable oxygen and carbon isotope analyses made originally with such studies in mind. Further, these analyses added to and compared with previous JOIDES and other results indicate long-range $0^{18} / \mathrm{O}^{16}$ trends in marine sediments (Figure 1).

This chapter should be read in conjunction with Chapters 13 and 20 of this volume (Schlanger et al.; Douglas and Savin) and the 167 Site Report.

Anderson and Schneidermann (in press) stated that the isotopic composition of upper Cretaceous limestone from Sites 146 and 153 (Leg 15, Caribbean) indicates a decrease in both $\delta \mathrm{O}^{18}$ and $\delta \mathrm{C}^{13}$ values with depth. This observed "oxygen shift" is postulated to have been caused by "cementation and recrystallization" of the limestone (Anderson and Schneidermann, in press). The cementation and recrystallization is then postulated to have been caused by high temperatures induced in the pelagic sediments by volcanic activity during late Cretaceous time in the region. This chapter will attempt to show that the high negative $\delta \mathrm{O}^{18}$ spike recorded by Anderson and Schneidermann in the Coniacian-Santonian interval may be a world-wide event and may not necessarily be caused entirely by volcanic activity.

\section{EXPERIMENTAL PROCEDURE}

Bulk samples of limestone and foraminiferal nannofossil ooze and chalk were washed with distilled water to remove soluble salts, reacted with a $5.25 \%$ sodium hypochlorite solution (Clorox) for 1 to 2 days to oxidize any organic carbon, and reacted with 100\% phosphoric acid (McCrea, 1950) to evolve carbon dioxide. The carbon dioxide was analyzed on a double-focusing, double-collecting isotope ratio mass spectrometer (Coplen, 1973) for oxygen and carbon isotopic composition. Corrections to the data for the impingement of more than two isotopic species upon the collectors were made after Mook (1968). The results are reported in the per mil notation relative to the Chicago PDB standard. All samples were analyzed in duplicate; the

\footnotetext{
${ }^{1}$ Contribution 73-11 of the Institute of Geophysics and Planetary Physics, University of California Riverside.
}

average deviations of the carbon and oxygen isotope analyses are $0.02^{\circ} \%$ and $0.05^{\circ} \%$, respectively.

One sample was prepared and analyzed without the sodium hypochlorite treatment. The isotope results were identical within experimental error; consequently, this treatment might not have been necessary. Two samples were size separated with a 200-mesh sieve. Both size-fractions were analyzed for isotopic composition.

\section{RESULTS}

The oxygen and carbon isotope analyses of samples in this study are listed in Table 1. The carbon dioxide yield is listed in terms of $\mu$ mole $/ \mathrm{mg}$.

\section{DISCUSSION}

The oxygen isotopic composition of the samples listed in Table 1 are shown in Figure 1, which is a plot of age versus oxygen isotopic composition. Temperatures at the bottom of Figure 1 were determined by assuming isotopic equilibration with water $0.0 \%$ relative to SMOW. The range in oxygen isotopic composition of our samples is $6 \%$, covering primarily the temperature range from $15^{\circ}$ to $29^{\circ} \mathrm{C}$. The oxygen isotopic composition of Sample 167-88-1, $140-153$ is $-5.46^{\circ} \%$, which corresponds to a paleotemperature of slightly over $40^{\circ} \mathrm{C}$. This clearly is an unreasonably high paleotemperature. There is no evidence in the section for a nearby volcanic intrusion which might explain this very high paleotemperature, and this sample does not appear to be altered. Therefore, we suggest that it probably is the consequence of a combination of a high oceanic temperature and a negative $\delta \mathrm{O}^{18}$ of Pacific Ocean water during late Berriasian to early Valanginian time.

Figure 1 shows the general decrease in $\delta \mathrm{O}^{18}$ of carbonates with age which has been pointed out by Anderson and Schneidermann (in press). This trend appears to be a world-wide phenomenon because it is observed in oceanic sediments from the deep-water environment of the Pacific Ocean, in sediments of the Caribbean (Leg 15), and in sediments deposited on shallow continental margins (western Europe; Lowenstam and Epstein, 1954). Each of the curves in Figure 1 displays decreases and increases in O18 abundance superimposed upon the general trend of decreasing $\mathrm{O}^{18}$ content with increasing age. Many of these features are correlatable between curves. Between Middle Miocene and Middle Eocene there is an increase in $\mathrm{O}^{18}$ content observed in sediments from Sites 167, 171, 47, and 55. During the Coniacian-Santonian there is a decrease in O18 content in the central Pacific, the Caribbean, and western Europe. Lowenstam and Epstein (1954) attributed the decrease to a change in oceanic temperature. In the central Pacific the negative $\delta \mathrm{O}^{18}$ "spike" is much more 

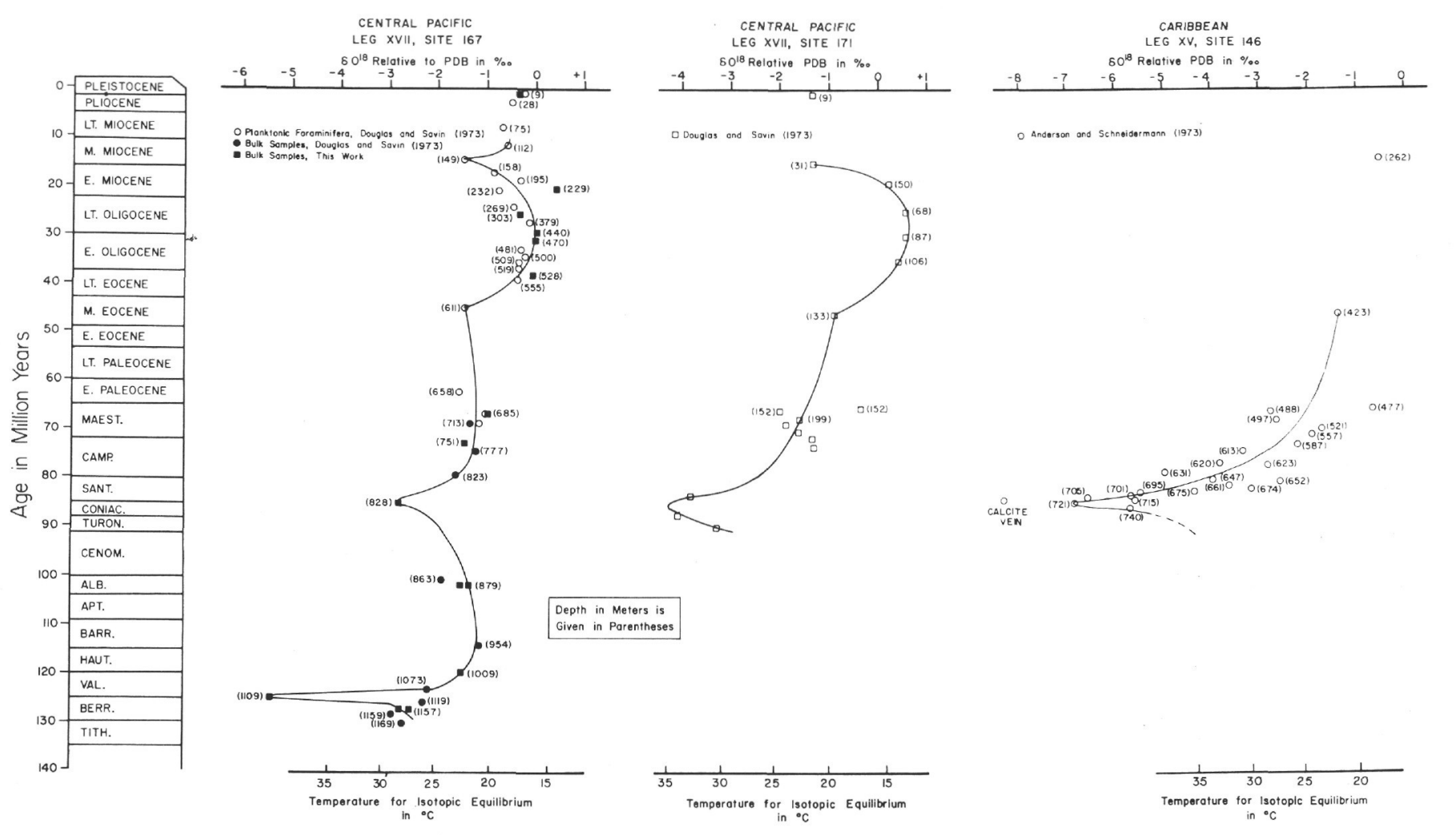

Figure 1. Age versus oxygen isotopic composition for samples from Sites 44, 47, 55, 146, 153, 167, and 171 and western Europe.

pronounced. This $\delta \mathrm{O}^{18}$ event is not correlatable with depth of burial, facies of deposition, or sedimentation rate.

The Coniacian-Santonian $\delta \mathrm{O}^{18}$ event at Sites 167 and 171 and the "Coniacian-Santonian temperature climax" of Lowenstam and Epstein (1954, p. 207) correlate exactly with the Site 146 and 153 event in the Caribbean (Anderson and Schneidermann, in press) as shown in Figure 1. Anderson and Schneidermann suggest that the very negative $\delta \mathrm{O}^{18}$ values are the result of submarine vulcanism. However, an association of high negative $\delta \mathrm{O}^{18}$ values in the Coniacian-Santonian sediments from Sites 167 and 171 with submarine intrusions or extrusive flows that could have caused high temperatures in these sediments is not indicated by the lithologic record. At Site 167 the record of volcanism is restricted to the extensive basement basalts that show no thermal effects on the overlying limestone (Site Report for 167, this volume). A tuff fragment was found in core-catcher 90; it may have caved from a zone of silty tuff several meters thick drilled in Cores 65 to 67 (late Albian age). The air gun record at Site 167 does not show any intrusive bodies. We suggest that the very negative $\delta \mathrm{O}^{18}$ values from the Coniacian-Santonian at Sites 146 and 153 might be the result of a coincidence of a volcanic event and an isotopic event-a case of reinforcement. Thus, we suggest that the Coniacian-Santonian event was a global isotopic one. If it were due only to a change in temperature, then a change of at least $7^{\circ} \mathrm{C}$ was required (site 171 in Figure 1). Thus, in a period of approximately 5 million years the temperature of the oceans increased about $7^{\circ} \mathrm{C}$; this rise was then followed by a decrease at approximately the same rate. Such rates of oceanic temperature changes of $1.4^{\circ} \mathrm{C} /$ million years require exceedingly high rates of heat accumulation and dissipation; the source and sink of this much heat may be a geophysical problem. A possible explanation for the decrease in $\mathrm{O}^{18}$ abundance in the carbonate sediments of the Coniacian-Santonian is a $1.5 \%$ to $2 \%$ decrease in $\delta \mathrm{O}^{18}$ of the oceans. However, Muehlenbachs (1971) has presented evidence that the $\mathrm{O}^{18}$ content of the oceans has remained constant during the last 200 million years due to the buffering action of oxygen in silicates in the mantle, via sea-floor spreading and mantle convection. Possibly the Coniacian-Santonian event is a combination of both an increase in oceanic temperature and a decrease in the $\mathrm{O}^{18}$ content by ocean water.

By assuming a $7^{\circ} \mathrm{C}$ rise in oceanic temperature during Coniacian-Santonian time, one might expect changes in the population, type, and habitat of oceanic biological species. There is some suggestion that this is the case. Lowenstam (personal communication) has observed shifts in the distribution of many species in the Atlantic region during Coniacian-Santonian time.

The high negative $\delta 0^{18}$ spike in the curve for Site 167 (Figure 1) during the Valanginian suggests a large temperature change, a large change in $0^{18} / \mathrm{O}^{16}$ of the Pacific, or both. Because there are no other oxygen isotope data for sediments from this stage, we cannot term this a global event. However, this possibility certainly exists. Again this raises important geophysical implications about the source and sink of heat if this shift in $\delta \mathrm{O}^{18}$ is due primarily to temperature.

Most of the samples studied for this chapter are lithified to varying degrees (Schlanger et al., this volume), but lithification has probably not affected their isotopic 

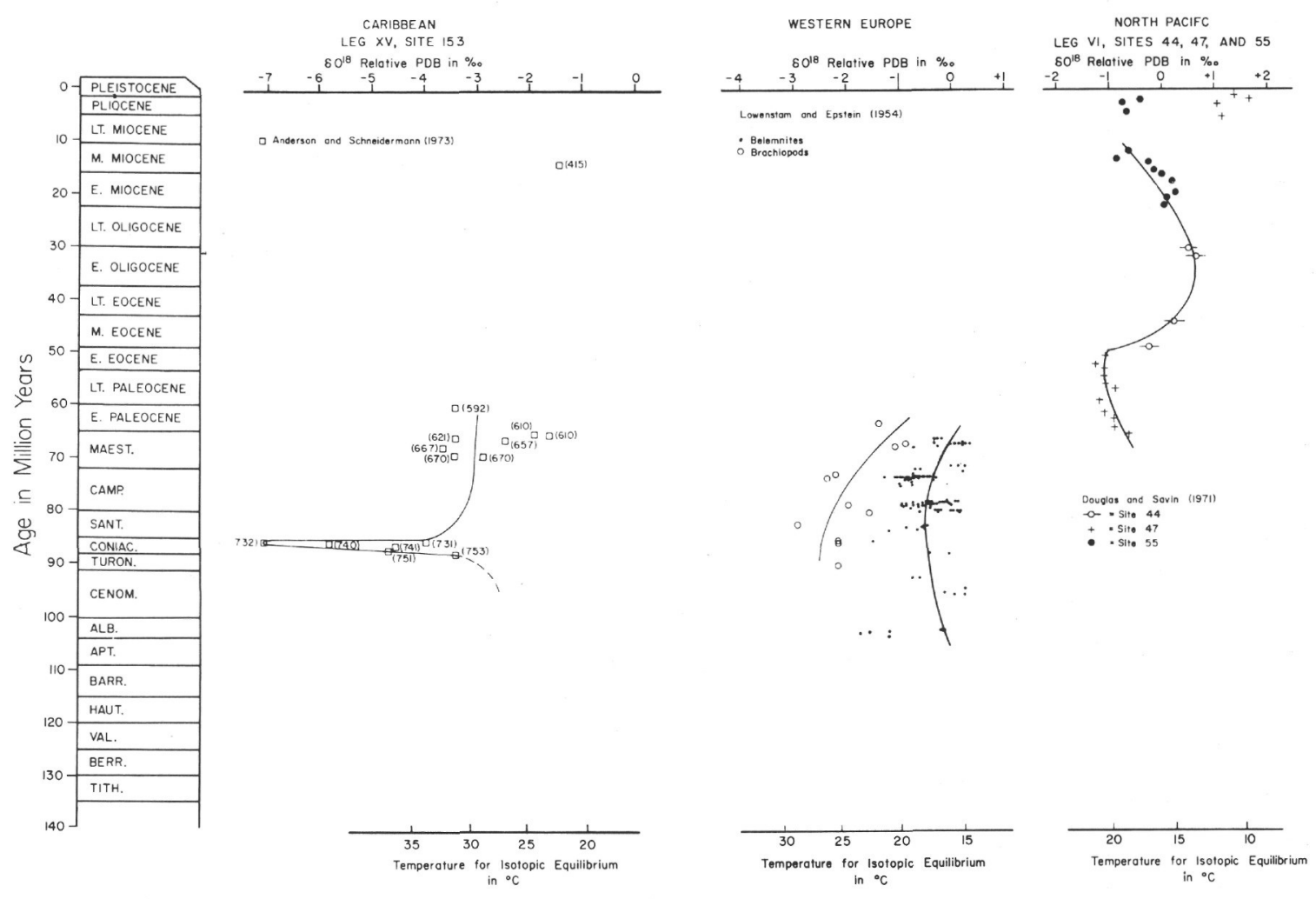

Figure 1. (Continued).

compositions significantly because oxygen isotopic equilibration is not observed over distances of meters. For instance, at a depth of 1109 meters $\delta \mathrm{O}^{18}$ is $-5.46^{\circ} \%$ o, while at 1157 meters $\delta \mathrm{O}^{18}$ is $-2.81^{\circ}$ \%o. It is possible that oxygen isotopic equilibrium has not been established over distances of centimeters. The water that has flowed through these sediments is merely the connate water expelled during the compaction of older sediments (Schlanger et al., this volume). Lloyd and Hsü (1972) have also suggested that there has been, on the whole, insignificant chemical exchange between oceanic carbonates sampled by the DSDP and interstitial waters.

Samples from barrels 63 and 92 were separated into $>200$-mesh and <200-mesh fractions. The carbon and oxygen isotopic compositions of both fractions from each barrel are nearly identical $\left(0.2^{\circ} \%\right.$ o difference $)$.

TABLE 1

Oxygen and Carbon Isotopic Composition of Bulk Carbonate Sediments from Leg 17, Site 167

\begin{tabular}{|c|c|c|c|c|c|c|}
\hline Sample & $\begin{array}{l}\text { Depth } \\
\text { (m) }\end{array}$ & Age & $\begin{array}{l}\mathrm{SO}^{18} \\
(\% \circ)\end{array}$ & $\begin{array}{l}\mathrm{SC}^{13} \\
(\%)\end{array}$ & $\begin{array}{c}\mathrm{CO}_{2} \text { Yield } \\
(\mu \mathrm{moles} / \mathrm{mg})\end{array}$ & Description \\
\hline $167-1-\mathrm{CC}$ & 9 & Pleistocene & -0.35 & +0.36 & 9.2 & Foraminiferal nannofossil ooze \\
\hline $167-9-4,141-143$ & 229 & Early Miocene & +0.40 & +1.99 & 8.3 & Foraminiferal nannofossil chalk-ooze \\
\hline $167-11-4,137-139$ & 303 & Late Oligocene & -0.34 & +1.04 & 8.3 & Foraminiferal nannofossil chalk \\
\hline $167-15-4,0-7$ & 440 & Late Oligocene & +0.00 & +1.34 & 8.4 & Foraminiferal nannofossil chalk \\
\hline $167-17-5,90-92$ & 470 & Early Oligocene & -0.01 & +1.55 & 8.7 & Foraminiferal nannofossil chalk \\
\hline $167-23-\mathrm{CC}$ & 528 & Early Oligocene & -0.08 & +1.81 & 8.8 & Foraminiferal nannofossil chalk \\
\hline $167-41-\mathrm{CC}$ & 685 & Late Maastrichtian & -1.01 & +1.01 & 8.7 & Chert, nannofossil ooze, and limestone \\
\hline $167-49-1,100-106$ & 751 & Late Campanian & -1.47 & +2.91 & 8.0 & Nannofossil ooze \\
\hline $167-58-1,121-123$ & 828 & Coniacian & -2.84 & +2.84 & 3.2 & Limestone, marly limestone, chert \\
\hline $167-63-\mathrm{CC}$ & 879 & Late Albian & -1.56 & +4.11 & 8.4 & $<200$ mesh limestone \\
\hline $167-63-\mathrm{CC}$ & 879 & Late Albian & -1.36 & +4.29 & 8.5 & $>200$ mesh limestone \\
\hline $167-78-1,148-150$ & 1009 & Early Hau terivian & -1.53 & +3.14 & 8.5 & Limestone and chert \\
\hline $167-88-1,140-143$ & 1109 & $\begin{array}{l}\text { Early Valanginian/ } \\
\text { Late Berriasian }\end{array}$ & -5.46 & +1.38 & 7.8 & Limestone and chert \\
\hline $167-92-\mathrm{CC}$ & 1157 & Late Berriasian & -2.81 & +1.66 & 9.3 & $<200$ mesh limestone and chert \\
\hline $167-92-\mathrm{CC}$ & 1157 & Late Berriasian & -2.60 & +1.69 & 9.1 & $>200$ mesh limestone and chert \\
\hline
\end{tabular}




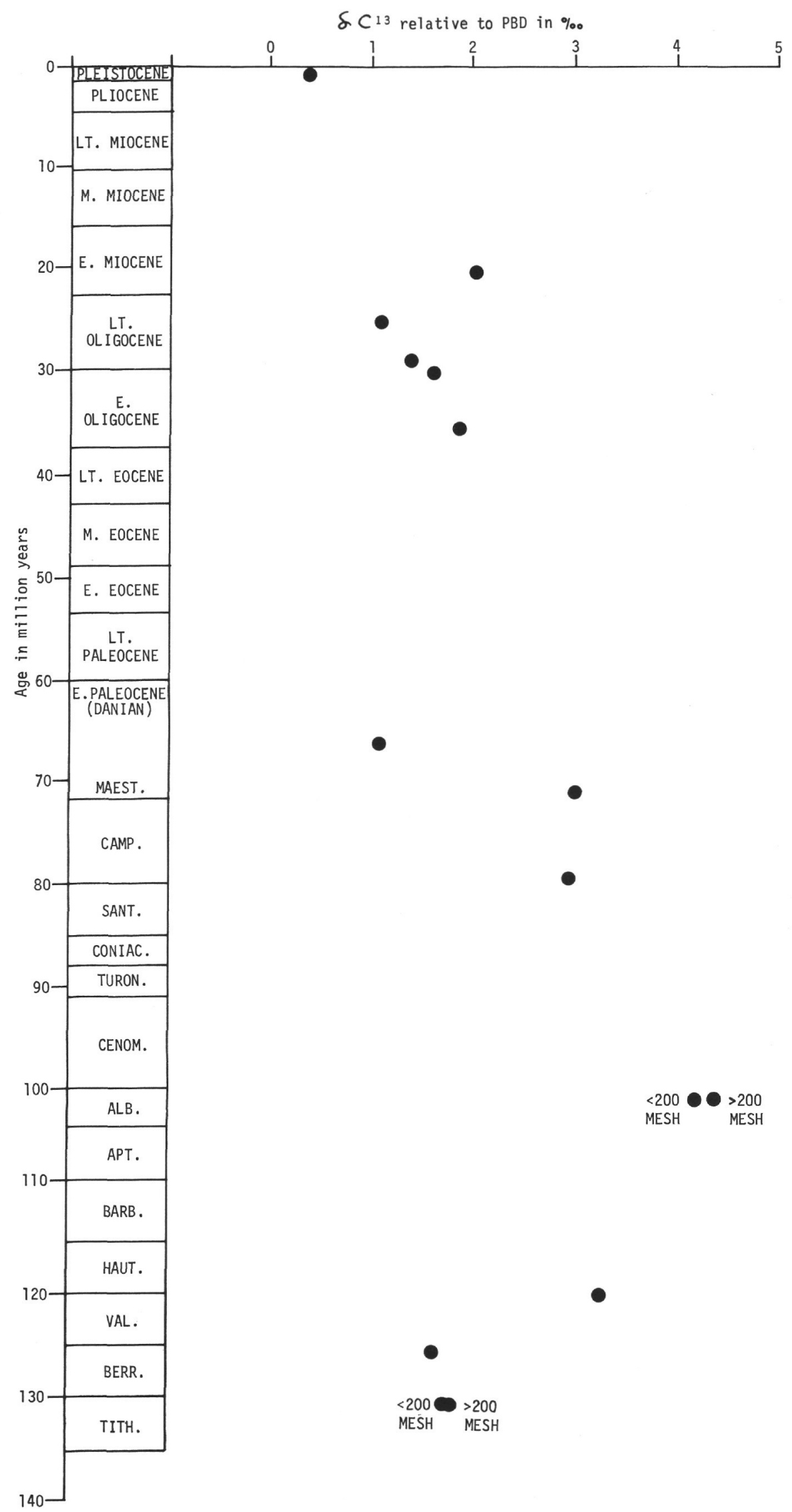

Figure 2. Age versus carbon isotopic composition of bulk samples from Site 167. 


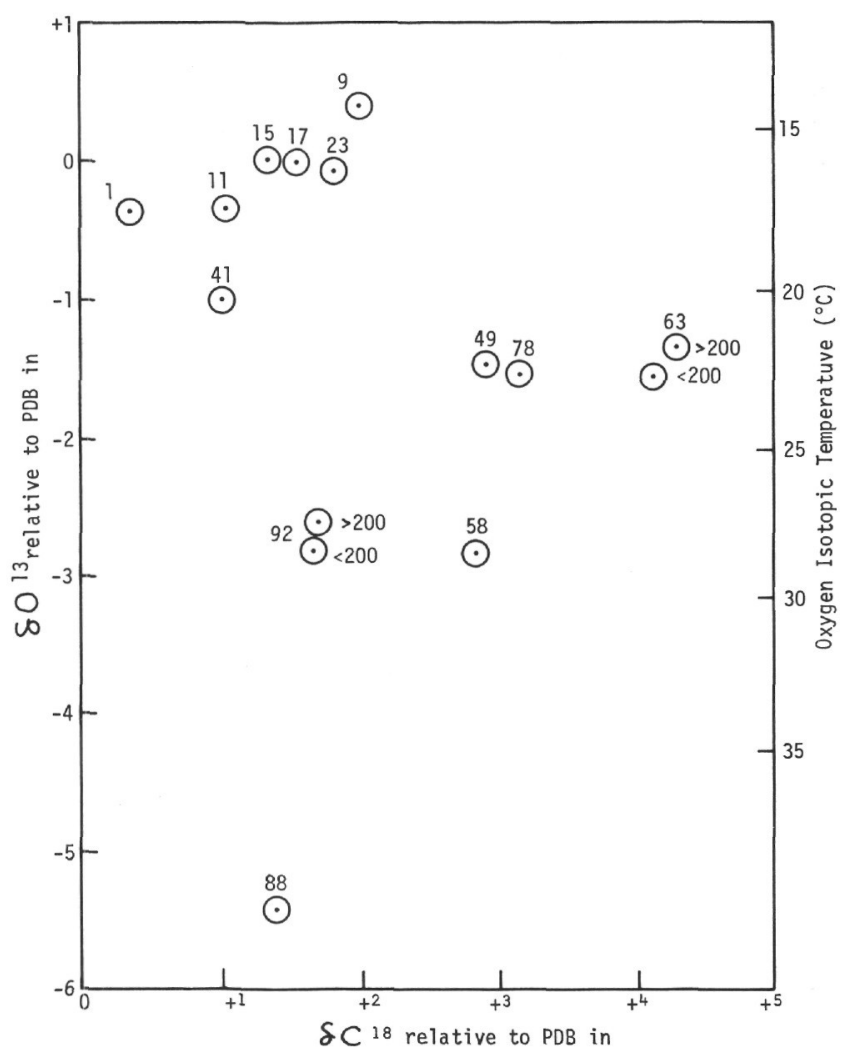

Figure $3 . \delta \mathbf{O}^{18}$ versus $\delta \mathrm{O}^{13}$ for bulk samples from Site 167. Barrel number is listed adjacent to each sample.

The carbon isotopic compositions from the bulk samples of Site 167 are plotted against depth in Figure 2. The range of compositions is similar to those observed at Sites 171 (Douglas and Savin, this volume); Sites 44, 47, 55 (Douglas and Savin, 1971); Sites 146 and 153 (Anderson and Schneidermann, in press). The exception is the sample from barrel 63 , which has an unusually high value of $+4.2 \%$. The reason for this is unknown at present. Figure 3, which is a plot of $\delta \mathrm{O}^{18}$ versus $\delta \mathrm{C}^{13}$, shows that there is little correlation between $\mathrm{O}^{18}$ and $\mathrm{C}^{13}$ abundance in the bulk samples from Site 167.

\section{ACKNOWLEDGMENTS}

We thank Robert Douglas and Thomas F. Anderson for their critical review of this article. This work was supported by the Institute of Geophysics and Planetary Physics of the University of California Riverside.

\section{REFERENCES}

Anderson, T. F. and Schneidermann, N. Stable isotope relationships in pelagic limestones from the central Caribbean: Leg 15, Deep Sea Drilling Project: Initial Reports of the Deep Sea Drilling Project, Volume XV. Washington (U.S. Government Printing Office), in press.

Coplen, T. B., 1973. A double-focusing double-collecting mass spectrometer for light stable isotope ratio analysis. Int. J. Mass Spectrom. Ion Phys., v. 11.

Douglas, R. G. and Savin, S. M., 1971. Isotopic analysis of planktonic foraminifera from the Cenozoic of the Northwest Pacific, Leg 6: Initial Reports of the Deep Sea Drilling Project, Volume VI. Washington (U.S. Government Printing Office), $p$.

Lowenstam, H. A. and Epstein, S., 1954. Paleotemperatures of the Post-Aptian Cretaceous as determined by the oxygen isotope method: J. Geol. v. 62, p. 207.

Lloyd, R. M. and Hsü, K. J., 1972. Stable-isotope investigations of sediments from the DSDP III cruise to south Atlantic: Sedimentology, v. 19, p. 45.

McCrea, J. M., 1950. The isotopic chemistry of carbonates and a paleotemperature scale: J. Chem. Phys., v. 18, p. 549

Mook, W. G., 1968. Geochemistry of the stable carbon and oxygen isotopes of natural waters in the Netherlands: $\mathrm{Ph} . \mathrm{D}$. thesis, University of Groningen.

Muehlenbachs, K., 1971. Oxygen isotope studies of rocks from mid-ocean ridges: Ph.D. thesis, Department of Chemistry, University of Chicago. 